\title{
THE REVIVAL OF PREHISTORIC BURIAL PRACTICES: THREE ARCHAEOLOGICAL EXPERIMENTS
}

\author{
Tõnno Jonuks, Marge Konsa
}

\begin{abstract}
The article presents the results of three burial experiments, carried out in 2005 , the aim of which was to attempt to understand what exactly happens to a physical body after death in different environments. The experiments were simulations of an open air burial, a stone cist burial and a cremation, for which the dead bodies of a calf and pigs were used. Next to technical documentation, the emotions and impressions of the experiment participants during the observations of body decomposition and the cremation process were recorded. The authors suggest that a cognitive approach to burial experiments could offer us an alternative view to understanding rituals and interpreting prehistoric burials.
\end{abstract}

Key words: experimental archaeology, burial experiments, cremation, cognitive archaeology

Bystanders often find it amazing how archaeologists constantly aspire to reconstruct societies consisting of complex human relationships and versatile behavioural patterns on the basis of mute artefacts. The nature of funerary practices, ritual systems, Weltanschauung and religion is surmised on the basis of the structure of burial places, extant skeletons and grave goods. In addition to analysing the funerary rituals and religion, burial material has been employed in researching the clothing, weaponry, and other mundane problems of the everyday life. In fact, archaeology has few means of its own for making interpretations. It is impossible to observe objects in the process of creation or use and there is nobody to ask from how, why and for which reason have certain objects been created or used. This is why archaeologists have relied on theories posed by anthropologists, sociologists, theologians, and other scholars of various fields which study modern living societies. The ambiguity of selection criteria, however, renders the popularity of certain theories and the adaptation of theories rather arbitrary.

In scholarly research of prehistory, authors are increasingly favouring experimental archaeology as a method for defining ways of interpretations. Experimental archaeology enables scholars to arrive at an understanding through 
personal participation. Even though interviewing people of the past or conducting participant observation in perished cultures is beyond the bounds of possibility, Julian Thomas (2001) argues that we can use our own bodies as analogues for those of the past. We may provide our own interpretation and in the course of the process identify the ways in which the past world differed from our world. And who knows, perhaps only personal experience will help to answer the questions which are often left unanswered or even remain unasked.

Does the material discovered from burials represent the reality of the past society or does it only provide an "idealised" view of the society - not what it is but what it is supposed to be (see Parker Pearson 2000: 32ff)? Is it possible to reconstruct the clothing of the living people on the basis of findings and parts of clothing discovered in burials, or does it only provide a reconstruction of burial clothes? During the past decade, various hypotheses have been posed on post-mortem rituals in Estonian archaeology (Kalman 1999; Lang 2000; Mandel 2003; Mägi 2002). Can these be associated with actual rituals conducted by people or may these be accounted for natural processes? What actually goes on inside a stone grave after a body has been placed there? How fast does flesh decompose and does it result in clean human bones that may have been used for carrying out rituals? How does a dead body actually decompose and which secondary rituals, if at all, could be performed on it? And, finally, where have most of the people of the past disappeared and how come only a small part of human remains have been preserved?

These and many other questions inspired the wish and the need to carry out an experimental archaeology project which came to be called Prehistoric Burials in Estonia. The few experiments conducted so far definitely cannot answer all the above questions. Even more so, each experiment elicited an increasing number of quite different problems which we could not even conceive at the stage of theoretical interpretation. Since in the course of the project's preliminary preparation it had become clear that this was going to be an interdisciplinary project, scholars of different fields were contacted. It was delightful to see that all scholars that were approached gladly agreed to join in the project, bringing along the traditions and research issues of their fields. ${ }^{1}$ All this enabled to expand the set of problems pertaining to the project and discover new aspects of it.

In 2005, three animal experiments were launched with an aim of imitating human burials. Two of the experiments involved inhumation and the third was a cremation burial. Regular observation of both inhumations was conducted. During each examination, air temperature and humidity was measured and the types of insects discovered on the bodies were determined. Soil 
samples were collected from under the burials, the comparative analysis of which before and after the experiment will hopefully prompt new problems and possibilities in the research of archaeological sites. All the experiments were documented: description was provided, they were photographed and recorded on videotape. Although the original intent was to analyse the findings from a purely scholarly viewpoint and provide figures and describe data as measurable, it soon became clear that the emotional response of experiment participants was far too intense to be left unrecorded. During the process, the experiments turned into a search for connections, links, associations and sources for inspiration of some sort. It was also found that the personal cognitive experiences of the participants opened a completely new field of understanding the burial process but also inspired new ideas. Observing the decomposition of a body evokes different emotions but also creates a good opportunity to test various hypotheses of secondary treatment of the body and bones.

The collected diverse biological data and results of various scholars will be published in forthcoming specialised articles after the material has been processed. This article introduces the general background of the burial experiments and the course of the project, describes the visual impact at different stages of the burials and discusses the possible interpretations of the different stages from ritualistic aspect. Considering that data accumulation will continue also in the future, current results should be regarded as an intermediary rather than a conclusive analysis of the end results of the project.

\section{BURIAL EXPERIMENTS}

Numerous studies have been conducted on the changes that human corpse undergoes after death and the process of body decomposition, though mostly by experts of forensic science and medicine rather than by archaeologists. The Body Farm or the University of Tennessee Forensic Anthropology Centre, ${ }^{2}$ the most famous institution using human bodies in forensic experiments, has carried out hundreds of observations of corpses since its establishment in 1981, and the results have been accumulated in an extensive database. As a rule, human corpses are not used for experiments outside this centre. Domestic pigs have been deemed the most acceptable animal model for these kinds of experiments, owing to the greatest physiological similarity with humans, including nutrition, digestion system, distribution of fat, skin tissue and hair growth, thus facilitating the comparison and unification of the terminology of decomposition processes (Dillon \& Anderson 1996: 8). 


\section{Body decomposition and determining factors}

Death may be viewed as a condition as well as a process. In individualist cultures, death symbolises an abrupt disruption - the end of life, whereas according to clinical criteria it signifies the irreversible cessation of all vital functions of an organism, marking the inescapable final stage of individual existence. In many cultures, death is perceived as a transition from one state of being to another, an intermediary stage in the endless process of transformations and alterations. This shows affinity with the biochemical view of death as the decomposing of a union in concert over a certain period of time, and its disintegration into particles which become linked to new cycles of substance and energy. During biological or cell death, enzymes get out of control and start rupturing cell membranes from inside. This is joined by the activity of bacteria, fungi, algae and other microorganisms constituting microflora, which turn tissues into gases, fluids and molecules. For many insect species, a corpse or carrion is the sole environment to guarantee the survival of the population.

The transformation of a lifeless body into clean white bones entails various stages of biological, chemical and physical transformations. Most of these changes can be directly followed - they are visually observable or can be perceived by smell and have functioned as one of the factors that shape culturespecific traditions and religious views.

Even though autolysis, or the breakdown of tissue by the action of enzymes, commences already a few minutes after death, the body still looks quite fresh for a while. Perceptible changes include the algor mortis of the corpse until reaching the ambient temperature, temporary rigor mortis of muscles, and livor mortis or post-mortem lividity caused by haemostasis. During warm weather, blowflies will arrive and lay eggs around body cavities. The beginning of putrefaction is marked by the perceptible swelling and bloating of the by then already greenish corpse. This brings about the release of gases (methane, hydrogen sulphide, etc.), which are the source of the distinctive putrid smell of corpses and, in turn, inform the insects and scavengers attracted to the corpse of an available food source. During intensive decay, the number of insects and larvae at different stages of development on the body is enormous and the bones are cleaned of flesh extremely fast, while the internal body temperature rises again owing to their activity. By this stage, all bodily fluids have left the corpse and soaked into the ground and the bloated carcass has sunken in. To the contrary of the internal body, which has turned into a creamy jellied biomass, the corpse has assumed blackened and desiccated appearance on the outside. Over time, insect larvae reaching adult stage start to leave the body to pupate 
and new larvae feed on soft tissues until these are completely destroyed. Compared to previous processes, the following skeletisation and diagenesis of the skeleton is a far slower process. The remains gradually dry, the bones are bleached, and the tendons, hairs and nails become destroyed. The bones left untouched on the ground may be covered by algae, lichen and mould, overgrown with vegetation, and become indiscernible in the landscape already before the bones have actually disintegrated (see further Vass 2001; Shepherd 2003: 37ff; Chamberlain \& Parker Pearson 2004, and literature referred to therein).

Various factors determine the course and speed of the decomposition process and thus the nature and length of the single stages of decay, as well as the process in general, greatly vary in each case. The most decisive of the variables, including the cause of death, body weight, age, etc. is the environment suitable for organisms affecting decomposition. For example, the majority of bacteria involved in the decomposition process of a corpse require enough warmth, humidity and neutral soil $\mathrm{pH}$ for their activity, and the number of different species and population of necrophagous insects also depend on the environmental and climatic conditions. Under favourable conditions, the bones may be cleaned of flesh within a few weeks, whereas in an environment low in oxygen (bog, high altitudes) or extremely arid environment (desert, or arctic regions), the corpse becomes mummified (Chamberlain \& Parker Pearson 2004). It is said that body in air will decompose twice as fast as one in water and at least four times as fast as one buried in the ground (Shepherd 2003: 46), although various additional factors (exposition, nature of soil, condition of the corpse, covering materials, such as a coffin or clothes, etc.) may alter the situation significantly.

Clearly, the decisive importance of the environment's biogeoclimatic conditions render the comparative analysis of burial experiments conducted in different regions nearly pointless. The majority of studies so far have been carried out in regions very far from Estonia. Using the research results from America or Australia, or even from other European countries, without presenting comparative local data, even if it is in the form of illustrative examples, is of dubious quality. Another questionable aspect is the method of documentation and the sphere of interest surrounding these experiments. From the viewpoint of forensic science and medicine, the conditions of burial experiments imitate accidents or crimes and the main purpose of these is to improve methods for identifying persons, time of death, the nature of injuries or criminal cause. Although physical anthropological information obtained in these experiments have proved an efficient means for explaining and interpreting various phenomena and pathologies in burials of the prehistoric and historic 
period, the viewpoint of archaeologists and archaeological burial experiments is still quite different from the discipline of physical anthropology but differs also from the purposes and documentation of cultural anthropologists (Levy 1982; Oestigaard 2000).

\section{The role of experiments in archaeology}

From the purely (natural) scientific perspective, experiments remain inconclusive for making claims about the past. Experiments are conducted at present time, their results do not allow testing or confirming theories about the past, and only enable us to speculate on their hypothetical validity or invalidity. Conducting experiments with the purpose of testing theories has been considered effective mostly in non-cultural areas, where universal understanding of matter-matter interactions apply (Hodder 1999: 21; Reynolds 1999). These experiments mainly focus on technology, the study of production and use of objects, but also on issues related to sediment and preservation processes of materials. Large-scale experiments have been carried out at imitational reconstruction of ancient burial structures and extremely longitudinal observations (e.g., Breuning-Madsen et al. 2001; Bell et al. 1996). Even if conducting the experiments in an environment as close to that of the past as possible is attempted, it is impossible to consider the randomness, irrationality or inconsistency of human behaviour in these experiments in any "controllable manner". In their research, archaeologists have neglected the regular and imminent observation of burials, and the cognitive and perceptible aspect of experiments is deemed important only for pedagogical or general educational purposes. Archaeological experiments may, in fact, yield interesting results in the study of cultural phenomena (ritual behaviour, and meaning), provided that the testing and established generalisations are dropped.

The aim of the experiments at hand was not and, in fact, could not be obtaining exact results of a specific archaeological monument or simulation of a specific type of burial. Even though burials have been excavated in Estonia in large numbers, information is relatively scanty on what kind of interaction of human behaviour and natural conditions has created the situation that can be seen in sites. Testing all possible variants would require very extensive series of experiments, and this is why these experiments focused on the search for basic and general information about what happens to a corpse after death. 


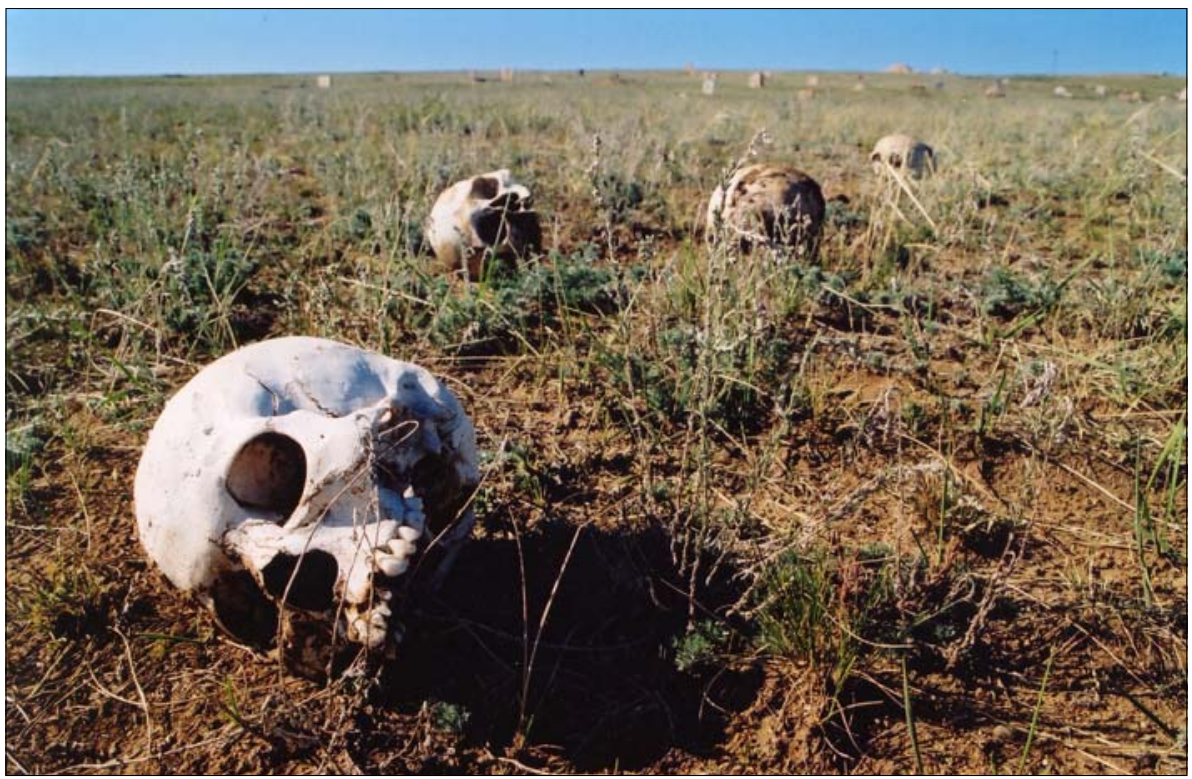

Figure 1. Burial ground in Mongolia. The dead have been left on a mountain slope, where birds feed on the earthly remains of the deceased and thus take their soul up to heavenly spheres. Photo by Mark Soosaar.

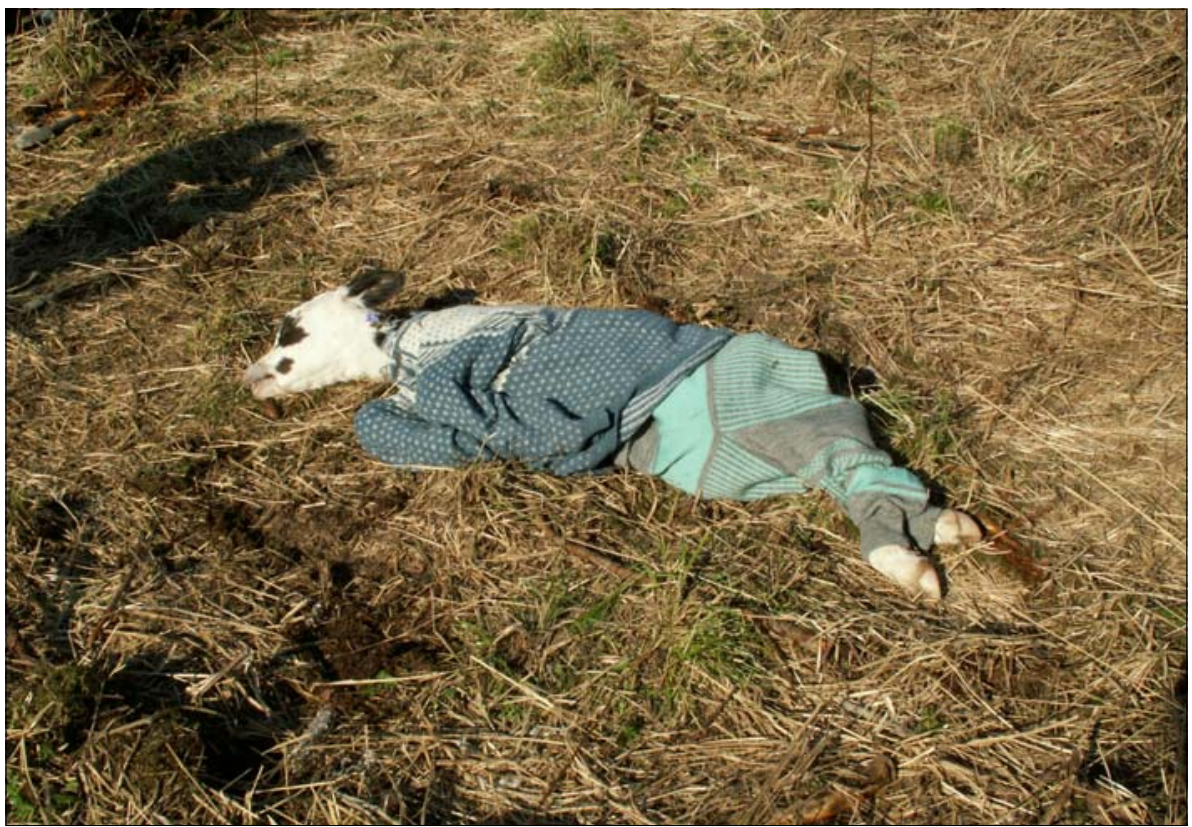

Figure 2. Calf burial. 


\section{OPEN AIR BURIAL}

Since leaving a body to decompose on the ground is one of the simplest and possibly the most popular type of prehistoric burials, an open air burial was chosen as the first experiment.

One of the aims of this experiment was to search for certain criteria (e.g., impact on the environment) which could possibly help to detect archaeological traces of corpses left on the ground in the future. The problem is set against the background of the so-called problem of the 'lost dead' in archaeological writing (Jaanits 1961; Atkinson 1968; Lang \& Ligi 1991). Various explanations have been offered as to why only a small number of corpses have been preserved until the present day. One possible and widespread explanation has been that the common practice was the abandonment of bodies at the "good mercy of Mother Nature" (see Bailey 2005: 116; and references therein). In Estonian tradition, it has been suggested that dead bodies may have been left on top of trees (Loorits 1949: 118), or cremated and the remains of cremation spread over water or in the air (Mägi 2002: 125), or corpses have simply been left to decompose on the ground over time (Jaanits 1961: 69). Parallels can be drawn between all these variants and contemporary cultures (see Fig. 1 on p. 97). Of course, all such speculations are impossible to confirm and remain only on the level of hypothesis. Still we believe that testing this type of burial could open up new research perspectives and may also sort out some unlikely ways of burying.

In this experiment a calf, died of diarrhoea at the age of one month, was used (see Fig. 2 on p. 97). The animal was placed on the ground in a former mixed forest glade. The calf was clothed in two woollen sweaters and adorned with a bouquet of spring flowers behind its ear. The carrion was examined every 7-10 days since its burial on May 2 until the end of the basic stage of decomposition in July. After this period, observations were continued over longer periods until November 2005.

The experiment team was first of the opinion that after leaving the carrion on the ground, it will pass two different stages - decomposition of the body and the emergence of clean bones. The actual process, however, proved far more complicated (see Table 1 at http://www.folklore.ee/folklore/vol37/tbl.htm). For the first few weeks no visual changes in the body could be noticed. The reason for that may have been the relatively cool weather in May, which enabled to keep the body fresh and postponed the putrefaction stage. No flies or carrion beetles could be seen on the body. At this stage, the burial left a pleasant, tranquil impression, resembling a dead person who does not evoke a repulsive response. In the report, this stage was referred to as the "stage of the dead person". 
Visible decomposition started on Week 2 of the experiment. During the decomposition period, the body looked admonitory, terrifying, and repulsive. There is an overall conception of dead body as something filthy and impure (see also Boyer 2001: 214). One of the crucial moments was when its eye(s) disappeared, after which the carrion assumed a non-personal appearance and began to look not like a dead person but rather like a repulsive "personalised death". This impression was emphasised by large black burying beetles and various insects flying around the carrion, some of them buzzing loudly. Part of the repulsive impression was definitely caused by the putrid smell surrounding the body. ${ }^{3}$ All this created a context rather different from everyday life. Emotionally, the carrion inspired an admonitory and rather repelling feeling. Attitudes towards the carrion set a considerable contrast with the stage of personalised death: while in the former stage it was a specific dead calf, then by this point it had lost its specific "personality" and left a terrifying non-personal impression. The empty eye cavity added to the spooky appearance, revealing the hollow skull and drawing a parallel with the traditional embodiment of death with its hollow eyes. The whole impression led to think of the forbidden or "taboo" stage - the period during which the deceased is dangerous, when its body and, if possible, the burial ground, should be best left undisturbed.

During the dangerous taboo period with carrion beetle succession on the calf's body and the body being bloated and repulsive, the first bones began to emerge. It took for about a month since the carrion was left on the site until its side touching the ground was completely clean. Compared to the decomposing and insect-swarmed body, the bare bones left a cleaner, "friendlier" and neutral impression. While observing the body's raised head, exposing both the bare half of the skull and the decomposing body behind it, it almost felt as if a new being was emerging - a non-personal, yet neutral dead. Compared to the previous stage, the difference lied in that the bones had turned more neutral and the repulsive appearance of the decomposing body and the sense of fear and danger brought about by this were gone. The sudden disappearance of the swarming mass of larvae must have also contributed to the more neutral impression. In the morning of the eighth day of the experiment, the calf's body was still filled with larvae - the entire body appeared to be as if alive, swarming with black beetles so numerous that the sweater around the carrion moved. By the following examination observation a week later, the beetles had gone. It was quiet and only a few remaining beetles were moving on the carcass, the entire body seemed abandoned and only the skeleton had remained. From this point on, the dead had the neutral, no longer terrifying appearance. Approximately four months after the burial, the site could not be seen from some 


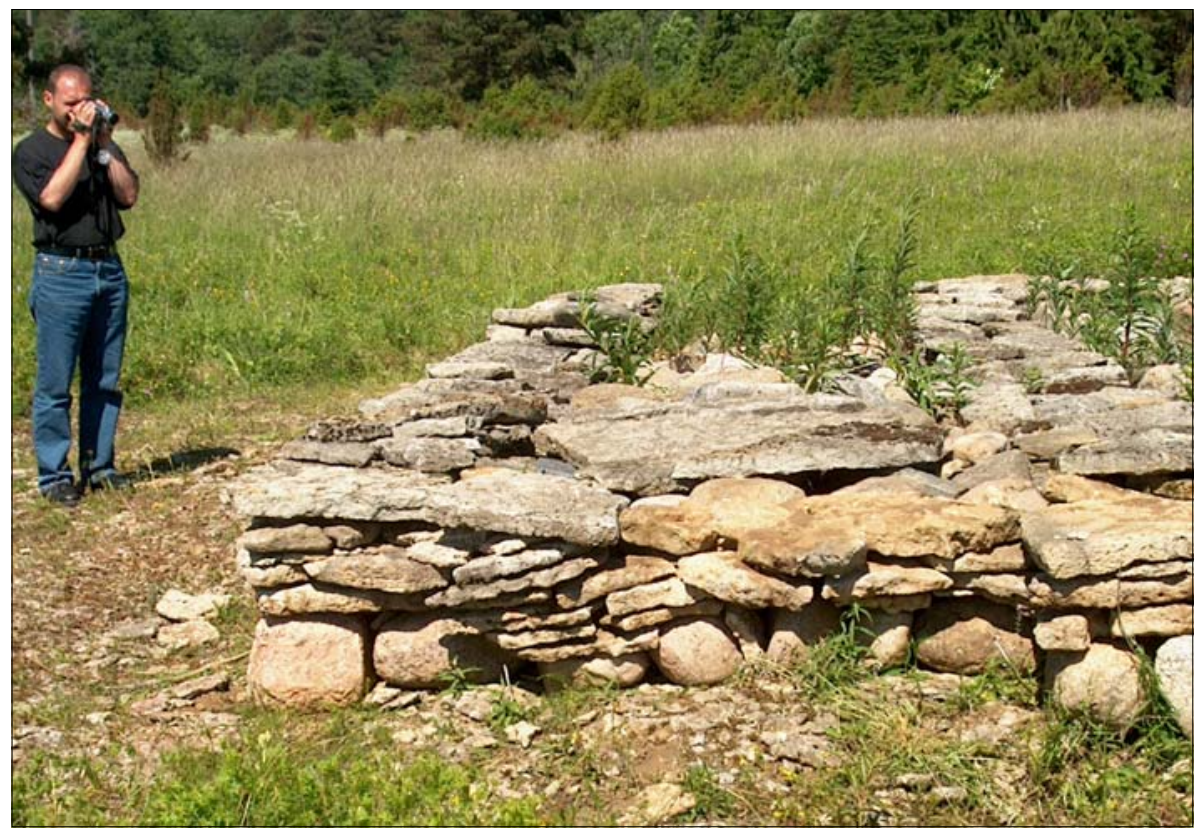

Figure 3. The reconstructed stone grave on the alvar used for the experiment.

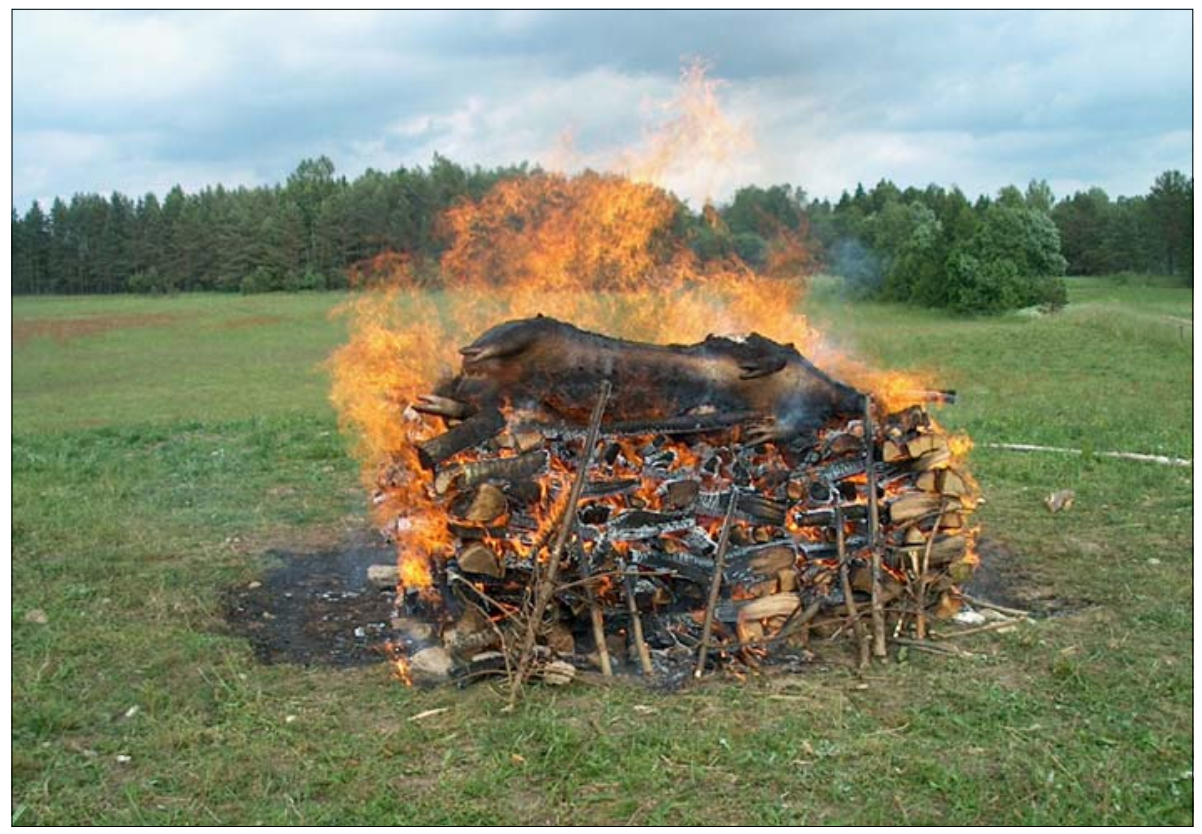

Figure 4. The cremation experiment in progress. 
distance, the moulding sweater had turned green and the skull covered with algae from the body proved difficult to be identified as a dead body.

In the course of the experiment the conviction that there is a considerable difference whether the body buried in this manner is clothed or not only strengthened. Carrion beetles required something around the calf to keep its flesh from drying out in the sun. In this experiment, woollen sweaters were used and the removal of the sweater exposed polished bones. Had the body not been clothed, the larvae would probably have preserved the skin. This, however, would have changed the overall visual appearance quite significantly.

The contrast with the so-called taboo period and the next stage of the new neutral deceased with clean bones was so remarkable that the latter stage left almost a friendly impression. Many archaeologists agree in this point (see, e.g., Brück 1995). This leads to a feeling that the deceased, who had formerly seemed hostile, had turned into non-personal dead, who appeared neutral and could probably be influenced or persuaded with sacrifice or certain mode of conduct.

The calf remained in this neutral stage until the end of the first phase of the experiment in 2005. Preliminary results of soil analysis ${ }^{4}$ reveal that the burial definitely has exerted influence on the landscape, though the stability and intensity of this influence have remained questionable at the moment. Observation of the carcass is to be continued after longer periods until the body is completely decomposed.

\section{INTERMENT IN STONE GRAVE}

Most scientific experiments of inhumation burials focus on analysing factors affecting sedimentary and preservation conditions. The results show that the grave structure, the used building materials, type of surface used for construction (soil, peat, sand) but also treatment of the dead body play a significant role in its preservation (e.g., Breuning-Madsen et al. 2001). Experiments taking into consideration the structure of stone cist grave and early tarand-graves in Estonia have not been carried out before. Relying on comparative archaeological data from interment in other countries (e.g., Brück 1995), it was speculated that the bones of the dead interred in graves were recurrently used in ancestral rituals after the burial (Jonuks 2003: 50), and members of the experiment team were mostly interested in the corpse's decomposition process in a covered stone cist, constructed on the ground.

An excavated and reconstructed stone cist grave located on an alvar of a few trees and shrubs, was chosen as the experiment location (see Fig. 3 on p. 
100). The experiment was carried out in summer with relatively dry and warm weather. The burial stones were lined with a rectangular stone cist covered after the burial with three larger limestone slabs. A domestic pig, died of enterocolitis at the age of six months, was chosen as the test subject. The pig was clothed in linen pants and its trunk was wrapped in a woollen carpet. A steel knife was placed under the clothes on top of the carrion, an unfinished bronze bracelet around its foreleg, some silver and bronze wire with a hanging bronze pendant around its ear, a thin bronze plate under its stomach and an iron spike under its back; and five bread loafs were left at the carrion's feet as grave goods. The burial was then covered with limestone slabs. In the course of further examinations, temperature and humidity were first measured outside and under the slabs without lifting these (under the slabs the air was constantly more humid and temperature nearly $10^{\circ} \mathrm{C}$ lower than outside the cist). The slabs were then removed and the general condition of the carrion documented (see more about the exact decomposition process Table 1 at http:// www.folklore.ee/folklore/vol37/tbl.htm).

Before the experiment it was speculated that in the stone cist burial, which was surrounded by a relatively thin layer of stones and was quite open to wind and humidity without sun drying the carrion off, decomposition would take place at a faster rate and result in clean bones. Furthermore, the experiment was conducted in summer when insect activity was at peak. This proved to be the case in the first few weeks of the experiment. A week after the burial, the carrion was swollen and numerous fly eggs could be detected on its scalp and neck. Intensive decomposition started during the third week and the corpse was invaded by carrion beetles. Beetle larvae started to quickly feed on the carrion, preferring areas covered by the woollen carpet (even though there was no direct sunlight over the burial), whereas insect succession to areas covered by thin linen followed somewhat later. By the end of Week 4, the carcass had collapsed, exposing the bare skull and humeri. During this period the entire burial and its surroundings were covered in black organic residue of so far undetermined origin. It is possible that these were food residue produced by larvae, which in the case of the open air burial had been washed into the surface by rain. As to the grave objects, the most significant changes had taken place with the bracelet and the knife: the bracelet displayed signs of oxidation by Week 5 and rust stains could be detected on the knife. The bread loafs placed at the foot of the carrion had disappeared during the third week after the burial.

Black residue around the burial, crawling beetle larvae, and permanently half-decomposed carrion created the same expression as during the taboo stage of the calf carrion, when the dead body appeared dangerous, repulsive and 
scary. Probably owing to a relatively higher temperature, the first stage of "the dead person" remained short in this experiment. The second peculiarity of stone cist burial was that the decomposition never resulted in clean bones. By a month and a half following the funeral, active decomposition had ended and beetles had left the carrion. Only bones covered with an even layer of black residue remained. This left the impression that the body remained at the dangerous stage. The stage of a neutral dead, which could be observed in the first experiment, had not arrived by 2005 .

The original opinion that the decomposition process takes place at a faster rate in a stone cist burial was refuted, since the results of this experiment suggest that access of rain to the corpse is relatively important in achieving clean bones (as these are generally considered key elements of rituals). The experiment must definitely be repeated under similar conditions to find out if these yield similar results. Also, examination of the experiment site needs to be continued to observe the further process of decomposition.

\section{CREMATION}

Followed by inhumation, cremation is the most popular type of burial throughout the world. As in decomposition of a corpse, the course and speed of the process in cremation burial depends on various factors: firewood, the structure of funeral pyre, position of the body, and weather. Compared to inhumation, during cremation the body transforms from one stage to another much faster and the entire process is often a collective and visual spectacle, as it can be observed at a single event. While during inhumation the body decomposes without human interference, cremation requires the active participation and action by performers of the ritual during the entire process.

Quite many cremation experiments have been carried out all over the world, though mostly by osteologists who focus on osteological issues and study the changes that bones undergo during cremation and later sedimentation, and possible factors influencing that (see Lange et al. 1987; Sigvallius 1994). Since compared to inhumation it is fairly difficult to obtain information about the dead person on the basis of cremated bones, numerous series of experiments centre on developing ways of estimating the number of individuals and their age on the basis of osteological material. Archaeologists have been mostly interested in determining the cremation sites or in tentative experiments testing a certain type of cremation (e.g., Gräslund 1978; Werner 1990). In Estonia, an experiment imitating female cremation burial was carried out during the Kuressaare Sea Festival in 1999 on a piglet, but no scientific data is available about 
the event. Quite recently, studies on what happens to funeral objects during cremation have been undertaken (Leineweber 2003), representing, in addition to observing the changes that a corpse undergoes during cremation, one of the focal points in this experiment.

\section{Description of the experiment}

Preparations for setting up the pyre were started on June 23 and the cremation was carried out the following day. The collection of burnt bones and artefacts was started on the same day immediately after cremation and was continued the next morning. Six weeks later, the cremation site was searched with metal detector.

The experiment was conducted on an adult sow (most likely died of stress), which weighed for about $100 \mathrm{~kg}$ ( 220 lbs) (see Fig. 4 on p. 100). A higher hillock in a glade was chosen as the cremation site. The pyre was constructed of $30 \mathrm{~cm}$ ( 12 inches) long cross-cut and cleft birch logs, which were stacked in layers, crosswise and lengthwise. A layer of stone was laid under the pyre for better ventilation. Two grooves were left in the middle of the pyre and filled with brushwood. A larger hole was left between the upper two firewood layers of the pyre and filled with tindery coniferous tree sprigs from the nearby forest. Another layer of logs was laid on top of it. The pyre (measuring $1.75 \times 1.2$ $\mathrm{m}$ or $5.7 \mathrm{x} 3.9 \mathrm{ft}$, and $85 \mathrm{~cm}$ or $\sim 33$ inches in height) was covered by a halfwoollen blanket on which the carrion was laid. A number of artefacts of various substances were placed on the pyre - bone, horn, bronze, silver, steel, cowry shells, clay pottery. Since the aim was to observe the reaction of various substances, the form of the objects was considered insignificant. The fire was lit from the two grooves in the middle of the pyre, the aim of which was to first set the upper part of the pyre on fire which would cause the heavy carrion to sink downward and set the lower layers of logs on fire. This method was more or less successful. From the moment the pyre was lit, the complete cremation process of the carrion lasted for six hours, resulting in only ashes and intensely cremated bones.

The experiment agreed with Howard Williams (2004: 271) who has noted that an open-air cremation burial may not be a quick, clean and clinical, little time- and energy-consuming activity, especially if those performing it have little experience. The choice of the pyre's location was determined by the consideration that a cremation burial, as an important collective event, must have been visually observable. It later turned out that the highest and the best observable site on the landscape was not a particularly good choice, as after lighting the pyre a strong wind picked up and carried most of the flames and 
heat away from the dead body. Also, two cubic meters $\left(\sim 70 \mathrm{ft}^{3}\right)$ proved too few to burn such large carrion. The short and relatively thinly cleft logs burned quickly and owing to the shortage of firewood procured in advance, the fire was kept up with windfall from the nearby forest (mostly coniferous trees, the amount of which is difficult to determine since it was added at the later stage of cremation).

Surprisingly, within an hour after the pyre was lit, the sow's skull had been burned clean and by the third hour of the experiment most of the bones were heavily cremated, whereas the burning of the carrion's flesh lasted until the extinction of the fire on the sixth hour (see Table 2 at http://www.folklore.ee/ folklore/vol37/tbl.htm). After the pyre was burnt, some bones were taken out on the same evening. Since the ashes were still hot and it was already turning dark, the final collection of cremated bones was postponed until the next morning. The total weight of bones left of the sow was $2.6 \mathrm{~kg}$ (5.7 lbs). Even though all the ashes were systematically shovelled through, some of the metal objects were not discovered until later with the metal detector. In sum, almost all objects placed on the funeral pyre were later found, including the processed bone and horn fragments and more than half of the cowry shells. Of the 22 metal objects placed on the burial, only two small bronze mounts remained missing.

Compared to the heavily cremated and mostly calcined bones, the impact of heat on the artefacts was uneven regardless of the six hours of intense cremation on the pyre (see Table 3 at http://www.folklore.ee/folklore/vol37/tbl.htm). Some objects had been disfigured beyond recognition, whereas some items had only been sooted. The experiment suggested that the extent of melting is rather random and has little to do with how the objects were originally placed on the pyre. Evidently, the bronze brooch originally placed under the side of the pig's trunk as well as the bronze mount placed on the side of the trunk proved to be disfigured the most. Some objects fell off the pyre at the very beginning of the experiment and were virtually untouched by fire, whereas many objects placed between the carrion and the pyre had not been melted, even though they must have fallen right in the middle of the most intense fire.

\section{CONCLUSION}

Two animal species were used in the above three experiments: a calf and two domestic pigs. While the use of animals, especially domestic pigs, is rather common in analogous experiments, the results should not be mechanically seen as valid for human burials, since there are considerable differences be- 
tween humans and either animal species. Calf's hairy skin and the relatively larger bone mass compared to soft tissues are clearly evident. As to domestic pigs, far too much soft tissue is distributed on their trunk; also, their limbs are shorter and with little muscle mass. The soft tissues of a human are distributed more evenly over the body, which, in turn, has an effect on both the decomposition process as well as the cremation. In the cremation experiment, the head and limbs of the subject animal were relatively quickly burned, whereas the internal soft tissues singed for a long time. The soft tissues of a dead human would have been more evenly distributed and thus more evenly cremated. As a rule, it has proven difficult to achieve the results of human cremation in cremating animals. After the cremation, about $2-2.5 \mathrm{~kg}(4.4-5.5 \mathrm{lbs})$ of bones is left of an adult human being, whereas the cremation of a pig of the weight of an average adult (approx. 50-70 kg or 110-150 lbs) yields the amount of bones that is comparable to those left of an infant; adult pigs, at the same time, tend to have too much flesh and fat mass for comparative results. Decomposition of an animal basically follows the same principle. In the described experiments, decomposition largely occurred inside the animal's body, whereas the activity was far less active around the limbs. The fleshy human limbs would have decomposed more actively (because of insect activity) and the entire decomposition process would have been more even.

In these experiments the ritual aspects of funerals were deliberately neglected, since the main aim was to experience and learn about processes that a dead body undergoes in different contexts. However, personal emotions and experiments have not been overlooked. All three experiments inspired emotions and associations in members of the experiment team. While the closest cognitive analysis will be the subject of another study, some general characteristics may be pointed out. At the earliest stage, all members of the experiment team associated the dead body with a rather tranquil and neutral dead person. At the following stage of decomposition, when the body was invaded by carrion beetles and larvae, the carrion assumed the characteristics of something dangerous and repulsive - this became to be referred to as the taboo stage. The impression was strengthened by beetles buzzing noisily around the corpse and the black organic residue around the body in the stone cist grave. Analogous emotional impact has been pointed out about Finno-Ugric sacred groves, which also emphasised the emergence of a new emotion, distinct from everyday life (Grachov 1995). While visiting the experiment sites, the participants claimed having felt the same. After the end, that is, at the final stage of intense decomposition the emotions were already quite different, since clean bones began to emerge from inside the decomposing carcass, creating a new association with a more neutral and even "friendlier" dead person. Parallels could be drawn 
between this stage and the transformation of the dead into a ritual object that is, the stage during which the bones of the dead may have been taken into use as elements of rituals. The conducted cremation experiment, during which the "deceased" body was first placed on the pyre, then set on fire, and the very fast change from an originally neutral dead into an indistinct black matter within three or four hours, triggered quite similar associations.

However, such conclusions can not be mechanically extended to all areas and all periods. It must be noted that the results of experiments exploring the interaction of human behaviour and tangible culture are only valid for the present - after all, the experiments are carried out by modern people with their moral values, skills and knowledge in a modern environment. The differentiation between the stages was also inspired by extensive documentation of every examination visit, which, in turn, focused our attention on phenomena that did not originally appear to be of any significance.

Personal experiments could be a key to understanding or interpreting past rituals. Obviously we can not reconstruct rituals based on our experiments, neither can we experience the same feelings that people did millennia ago, when they buried their deceased or performed rituals. But seeing what happens with the main object of a funerary ritual offers a new perspective and poses new questions for understanding this. And, certainly, points to the weaknesses in some theoretical constructions.

\section{ACKNOWLEDGEMENTS}

In addition to all the people mentioned in the article, very many others took part at the various stages of the project. We would like to express our gratitude to all these people - especially farmers who donated us the "dear departed". The project was financed by the Estonian Cultural Endowment. The article was completed with the support of the basic-funded research topic Interdisciplinary archaeology: Interactions of the culture and natural environment of the past and the Estonian Science Foundation grant no. 6686.

Authors are grateful to Kait Tamm and Kristiina Johanson for translating and consulting us on the text. 


\section{COMMENTS}

${ }^{1}$ Osteological analysis was conducted by Lembi Lõugas, $\mathrm{PHD}$, and Liina Maldre from the Institute of History, University of Tallinn. Raili Allmäe from the same institution was involved in the cremation experiment. Microanalysis of bones was carried out by Kurmo Konsa, PHD, docent at the Chair of Archival Studies, University of Tartu. Necrophagous insects were determined and scholars unfamiliar with entomology were educated by Mati Martin, PHD, docent at the Institute of Zoology and Hydrobiology at the University of Tartu. Surface samples collected in the vicinity of and under the burials were analysed by Jaana Konist at the Department of Pedology and Agrochemistry of the Institute of Agricultural and Environmental Sciences, Estonian University of Life Sciences; the plant community was determined by Triin Pärnaste.

${ }^{2}$ The institute's home page is available at http://web.utk.edu/ anthrop/FACcenter.html.

${ }^{3}$ Whenever necessary, rubber gloves and respirators were used in carrion examination. Thus, none of the examination team came to direct contact with the corpse. Still the foul stench from corpse could be smelled for the entire observation day. Imagining the occurrence of a similar situation in a prehistoric burial ground suggests that every visit to the dead body must have left an indelible impression for the entire day, if not even longer. Thus it is likely that such burial grounds became extraordinary rather than commonplace areas, and it is difficult to imagine that such sites were visited regularly without an urgent need to bury people there.

${ }^{4}$ Soil samples from under the calf's carcass and in the background environment were collected imminently before the burial and four months later. The analysis of migratory elements conducted by the present moment shows that potassium and calcium levels had significantly fallen in the surface under the burial (preliminary report by Jaana Konist (2005)).

\section{REFERENCES}

Atkinson, Richard 1968. Old Mortality: Some Aspects of Burial and Population in Neolithic England. In: J. M. Coles and D. D. A. Simpson (eds.). Studies in Ancient Europe: Essays presented to Stuart Piggott. Leicester: Leicester University Press, pp. 83-93.

Bailey, Douglass W. 2005. Prehistoric Figurines. Representations and Corporeality in the Neolithic. Routledge.

Bell, Martin \& Fowler, Peter \& Hillson, Simon (eds.) 1996. The Experimental Earthwork Project 1960-1992. York: Council for British Archaeology.

Boyer, Pascal 2001. Religion Explained: The Evolutionary Origins of Religious Thought. New York: Basic Books.

Breuning-Madsen, Henrik \& Holst, Mads K. \& Rasmussen, Marianne 2001. The Chemical Environment in a Burial Mound Shortly after Construction - An Archaeological-Pedological Experiment. Journal of Archaeological Science, 28, pp. 691-697. 
Brück, Joanna 1995. A Place for the Dead: The Role of Human Remains in Late Bronze-Age Britain. Proceedings of the Prehistoric Society, 61, pp. 245-277.

Chamberlain, Andrew T. \& Parker Pearson, Michael 2004. Earthly Remains: The History and Science of Preserved Human Bodies. London: The British Museum Press.

Dillon, Leigh \& Anderson, Gail 1996. Forensic Entomology. The Use of Insects in Death Investigations to Determine Elapsed Time since Death in Interior and Northern British Columbia Regions. Technical report. Canada. Available at http://www.cprc.org/ tr/tr-1996-03.pdf, last accessed in May 2006.

Grachov, Oleg 1995. Civil Engineering Aspects of the Formation of Mansi and Udmurt Worship Complexes. In: Mare Kõiva and Kai Vassiljeva (eds.) Folk Belief Today. Estonian Academy of Sciences, Institute of the Estonian Language \& Estonian Museum of Literature. Tartu, pp. 66-71.

Gräslund, Anne-Sofie 1978. Bränning på platsen eller särskild bålplats? Några notiser om ett bränningsförsök. Tor, 1975-77, Vol. 17. Uppsala, pp. 363-373.

Hodder, Ian 1999. The Archaeological Process. An Introduction. Blackwell Publishers.

Jaanits, Lembit 1961. Jooni kiviaja uskumustest. In: Religiooni ja ateismi ajaloost Eestis (Characteristic beliefs of the Stone Age), Vol. 2. Tallinn, pp. 5-70.

Jonuks, Tõnno 2003. Eesti metalliaja usundi põhijooni (Main principles of Estonian religion during Metal Ages). MA thesis. University of Tartu. Manuscript held at the Tartu University Library.

Kalman, Jonathan 1999. Human Remains from the Stone Cist Graves of Rebala Lastekangrud, North Estonia. Eesti Arheoloogia ajakiri. Journal of Estonian Archaeology, 3 (1), pp. 3-18.

Konist, Jaana 2005. Mullaanalüüs eksperimentaalsest matusekohast (Soil analysis of an experimental burial). Unpublished manuscript.

Lang, Valter 2000. Keskusest ääremaaks. Viljelusmajandusliku asustuse kujunemine ja areng Vihasoo-Palmse piirkonnas Virumaal (From core to periphery. Formation and development of cultivation economic settlement in Vihasoo-Palmse region, Viru County). In series: Muinasaja teadus, 7. Tallinn-Tartu.

Lang, Valter \& Ligi, Priit 1991. Muistsed kalmed ajaloolise demograafia allikana (Prehistoric burials as a source of historical demography). In series: Muinasaja teadus, 1, pp. 216-238.

Lange, Martina \& Schutkowski, Holger \& Hummel, Susanne \& Herrmann, Bernd 1987. A Bibliography on Cremation. PACT, 19. Strasbourg: Council of Europe, Parliamentary Assembly.

Leineweber, Rosemarie 2003. Brandneu - Verbrennung auf dem Scheiterhaufen oder - Studie über branddeformierte Beigaben aus Brandgräbern der römischen Kaiserzeit Innergermaniens. - Experimentelle Archäologie in Europa, Bilanz 2002. Heft 1, Oldenburg, pp. 159-172.

Levy, Janet E. 1982. Social and Religious Organization in Bronze Age Denmark. An Analysis of Ritual Hoard Finds. BAR International Series, 124. Oxford.

Loorits, Oskar. 1949. Grundzüge des Estnischen volksglaubens 1. Skrifter utgivna av Kungl. Gustav Adolfs Akademien för Folklivsforskning, 18:1, Lund: Carl Bloms Boktryckeri. 
Mandel, Mati 2003. Läänemaa 5.-13. sajandi kalmed (5th-13th century burials in Lääne County, West Estonia). Eesti Ajaloomuuseum. Töid ajaloo alalt, 5. Tallinn.

Mägi, Marika 2002. At the Crossroads of Space and Time. Graves, Changing Society and Ideology on Saaremaa (Ösel), 9th-13th Centuries AD. CCC papers, 6. Tallinn.

Oestigaard, Terje 2000. The Deceased's Life Cycle Rituals in Nepal. Present Cremation Burials for the Interpretations of the Past. BAR International Series 853, Oxford.

Parker Pearson, Mike 2000. The Archaeology of Death and Burial. Texas A\&M University Press.

Reynolds, Peter J. 1999. The Nature of Experiment in Archaeology. In: A. F. Harding (ed.) Experiment and Design: Archaeological Studies in Honour of John Coles. Oxbow Monographs Series, 8. Oxford: Oxbow, pp. 156-163.

Shepherd, Richard 2003. Simpson's Forensic Medicine. London.

Sigvallius, Berit 1994. Funeral Pyres. Iron Age Cremations in North Spånga. Theses and Papers in Osteology, 1. Stockholm, pp. 15-32.

Thomas, Julian 2001. Archaeologies of Place and Landcape. In: I. Hodder (ed.) Archaeological Theory Today. Polity Press, pp. 165-186.

Vass, Arpad A. 2001. Beyond the Grave - Understanding Human Decomposition. Microbiology Today, 28, pp. 190-192.

Werner, Achim 1990. Versuche zur Rekonstruktion provinzialrömischer Brandbestattungen vom Typ Bustum. Experimentelle Archäologie in Deutschland. Begleitschrift zu einer Ausstellung des staatlichen Museums für Naturkunde und vorgeschichte Oldenburg. Archäologishe Mitteilungen aus Nordwestdeutschland, Beiheft 4, pp. 227-230.

Williams, Howard 2004. Death Warmed Up. The Agency of Bodies and Bones in Early Anglo-Saxon Cremation Rites. Journal of Material Culture, Vol. 9 (3), pp. 263291. 